\title{
FEASIBILITY STUDY OF TRAFFIC AND ECONOMY IN BANYUDONO - KARTASURA HIGHWAY
}

\author{
Intan Nuril Karimah ${ }^{1}$, Nafiah ${ }^{2}$ \\ ${ }^{1,2}$ The Department Master of Civil Engineering, Faculty of Engineering, Sultan Agung Islamic University, Jl. \\ Raya Kaligawe Km. 4 Semarang, 50112, Indonesia \\ Corresponding Author Email: nafiah@unissula.ac.id
}

\begin{abstract}
Population and economic growth in Central Java Province continues to increase. One of the segments from the highway of Semarang-Solo is Banyudono-Kartosuro, this segment is one of the main segments that links Semarang and Solo, so stacking of vehicle volume in this region often happens. With this background, this study is entitled Feasibility Study of Traffic and Economy in BanyudonoKartasura Highway.Analyzing the traffic aspect requires several parameters by estimating the volume of the vehicle or weather forecast, the degree of saturation and also the trip assignment value. In addition, for the economic aspects in terms of road users by calculating the value of Benefit Cost Ratio (BCR), Net Present Value (NPV), and Internal Rate of Return (IRR). Based on the forecast results obtained an outcome that in the year of 2027 for Boyolali-Kartosuro segment will experience congestion and after the built of highway, congestion will decrease in 2038, for Salatiga-Boyolali segment congestion will occurred in 2029 and after the built of highway congestion occurred in 2040. For the calculation of feasibility of economic analysis value obtained $B C R=4.3>1, N P V=R p$ $3,409,646,232,099>0$, and $I R R=12.26>4.48 \%$.
\end{abstract}

Keywords: Traffic feasibility, Economic growth, Banyudono-Kartosuro Highway

\section{INTRODUCTION}

Central Java Province is one of the provinces in Indonesia which is located very strategically on the Java Island. Located in the center of Java Island makes the Province of Central Java become the main transportation routes for mobilization activities of all societies. One of the efforts to overcome traffic congestion in Central Java, the Central Java Provincial Government and Central Government plan to develop Trans Java Highway, one of them is Semarang-Solo Highway. The Semarang-Solo Highway is divided into five sections, namely Section 1 (Semarang-Ungaran), Section 2 (Ungaran-Bawen), Section 3 (Bawen-Salatiga), Section 4 (Salatiga-Banyudono), and Section 5 (Banyudono- Kartasura).

This Highway of Banyudono-Kartasura has a length of $7.8 \mathrm{~km}$ that pass through Boyolali and is connected to Kartasura, where traffic conditions in that area are already density and with the Banyudono-Kartasura highway development project, it is expected that the road 
access will be smoother for road users and can also shorten the mileage time so that it can solve frequent congestion problems.

In this case to analyze the traffic condition of Banyudono-Kartasura area before and after the built of highway, and the feasibility of the development of this highway in technical economics to be implemented.

\section{METHODOLOGY}

There are two types of data used for this research, namely:

1. Primary data is data obtained directly from conducting traffic surveys in the field. Methods of data collection can be done by observation at two location points, which is on the main road of Boyolali-Kartosuro and Salatiga-Boyolali segment.

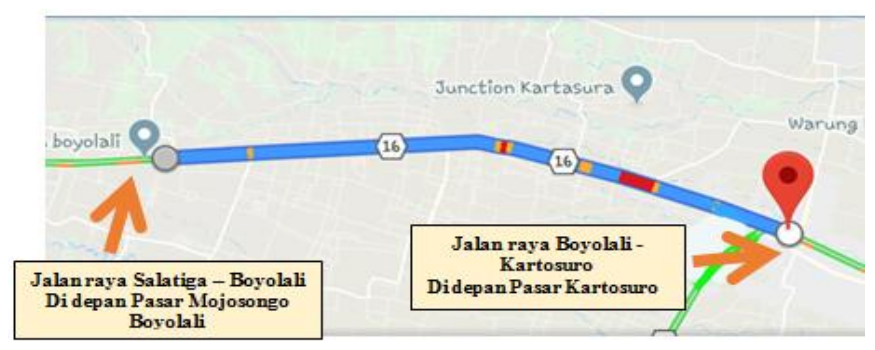

Figure 1. Survey Location Map

2. Secondary data, is data from relevant agencies, books, journals, laws, ministerial decisions etc., consisting of:

a. Indonesia Road Capacity Manual 2014 as a reference to determine the value of coefficients on the road parameters and the formulas used.

b. Income Data of Regional Gross Areas (PDRB), obtained from Central Bureau of Statistics (BPS) of Central Java Province, to calculate the forecast of private vehicles and industrial vehicles. Table 3.2 Domestic Product of Regional Gross (PDRB) on the basis of Constant Price of Central Java Province year 2009-2013 to calculate the forecast of industrial vehicles.

c. The value of unit price of goods as a reference to get the value of Operational Cost of vehicle (BOK), this data is used to calculate the amount of BOK savings. The BOK cost factor is included in the secondary data. 
d. Contract value determination of Banyudono-Kartasura Highway project and other costs related to project development, also the value of maintenance and operational of the highway obtained from PT. Trans Marga Jateng.

\section{DISCUSSION}

1. Data Processing and Traffic Aspects Discussion

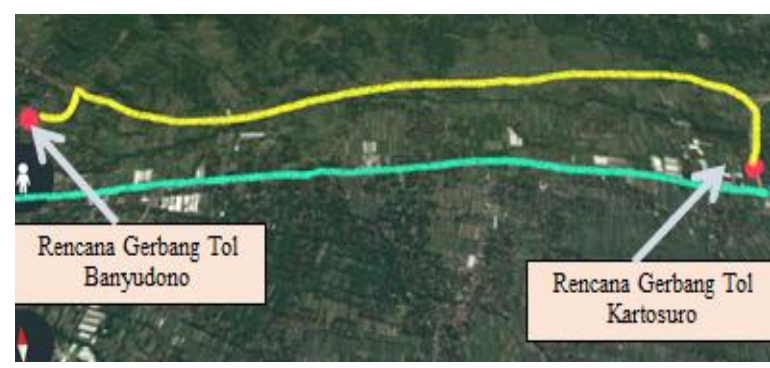

Figure 2. Research Location Map

a. Income Data of Regional Gross Areas (PDRB)

Table 1. Product Domestics of Regional Gross (PDRB) Province Per Capita Central Java Province 2011-2013

\begin{tabular}{cccc}
\hline Province & \multicolumn{3}{c}{ Per Capita PDRB } \\
\hline Central & $\mathbf{2 0 1 1}$ & $\mathbf{2 0 1 2}$ & $\mathbf{2 0 1 3}$ \\
\cline { 2 - 4 } Java & $6,058,604$ & $6,399,599$ & $6,706,874$ \\
\hline Source: Central Java Provincial BPS, 2016 &
\end{tabular}

Calculation example of per capita PDRB growth in 2011-2012

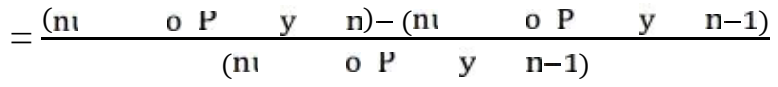

$$
\begin{aligned}
& =\frac{6 \quad-6}{6} \\
& =6 \%
\end{aligned}
$$

b. Traffic Counting Survey Data

Table 2. Traffic Counting Data Survey of Salatiga - Boyolali Road

\begin{tabular}{cccccccccccc}
\hline hour & MC & LV & LV & LV & MHV & LB & MHV & LT & LT & LT & LT \\
\hline & Spd mtr & Mbl & Angk & Pck & Bus K & Bus B & 2As4R & 2As6R & 3As & TG & TS \\
\hline $16-17$ & 2864 & 872 & 150 & 225 & 10 & 128 & 40 & 200 & 56 & 4 & 50 \\
\hline
\end{tabular}

Source: Calculation and Analysis, 2018 
Table 3. Traffic Counting Data Survey of Boyolali-Kartasura Road

\begin{tabular}{llllllllllll}
\hline hour & MC & LV & LV & LV & MHV & LB & MHV & LT & LT & LT & LT \\
\hline & Spd mtr & Mbl & Angk & Pck & Bus K & Bus B & 2As4R & 2As6R & 3As & TG & TS \\
\hline $16-17$ & 3164 & 1020 & 160 & 230 & 12 & 130 & 42 & 200 & 54 & 4 & 48 \\
\hline
\end{tabular}

Source: Calculation and Analysis, 2018

c. Technical Support Data

In analyzing the feasibility of Banyudono-Kartasura Highway development, it is also necessary to know the characteristics of existing roads reviewed.

i. Road of Salatiga-Boyolali

Road Type: 4 lane 2 way with median (4 / 2T)

Effective Road Width: $7 \mathrm{~m}$

Shoulder Width: $1.5 \mathrm{~m}$

Length of Road: 7.800 m

ii. Road of Boyolali-Kartasura

Road Type: 4 lane 2 way with median (4 / 2T)

Effective Road Width: 7 m

Shoulder Width: $1.5 \mathrm{~m}$

Length of Road: $7.800 \mathrm{~m}$

d. Analysis of Traffic Volume (without project)

The following calculation of traffic volume in both existing road segments based on traffic survey data multiplied by the equivalence factor ( $\mathrm{smp} /$ hour) and then divided by the daily traffic volume equivalence factor, the result is as follows:

Table 4. Daily Traffic Volume of Boyolali - Kartasura Road

\begin{tabular}{lllllllllll}
\hline MC & LV & LV & LV & MHV & LB & MHV & LT & LT & LT & LT \\
\hline Spd mtr & Mbl & Angk & Pck & Bus K & Bus B & 2As4R & 2As6R & 3As & TG & TS \\
\hline 14381 & 9272 & 1454 & 2090 & 145 & 1772 & 500 & 4545 & 1227 & 91 & 1091 \\
\hline
\end{tabular}

Source: Calculation and Analysis, 2018 
Vol 23 No 1 Tahun 2018

Table 5. Daily Traffic Volume of Salatiga - Boyolali Road

\begin{tabular}{lllllllllll}
\hline MC & LV & LV & LV & MHV & LB & MHV & LT & LT & LT & LT \\
\hline Spd mtr & Mbl & Angk & Pck & Bus K & Bus B & 2As4R & 2As6R & 3As & TG & TS \\
\hline 13018 & 7972 & 1363 & 2045 & 118 & 1745 & 472 & 4545 & 1272 & 90 & 1136 \\
\hline
\end{tabular}

Source: Calculation and Analysis, 2018

e. Road Calculation prior to highway project

From the calculation of daily traffic volume multiplied for one year (365 days) then projected over 30 years of age plan based on PDRB growth rate of 6\%, this calculation yields an estimated annual traffic volume for thirty years.

f. Degree of Saturation Calculation Without Project

Calculation of degree of saturation with the formula of DJ $=\mathrm{Q} / \mathrm{C}$, based on annual traffic volume above, obtained the result that in the year of 2027 in BoyolaliKartasura segment will experience congestion, and in 2029 for Salatiga-Boyolali segment also will experience congestion.

g. Flow Rate Analysis

Determining the average speed on existing roads and highway, as big as

Road of Banyudono-Kartasura $=61.64 \mathrm{~km} / \mathrm{h}$

Highway $=79.52 \mathrm{~km} / \mathrm{hr}$

h. Trip Assignment Analysis

Based on the results of several calculations above then calculated the estimated movement of vehicles that still remain in the existing road and highway with smock method obtained the results of:

i. Road of Boyolali-Kartasura : percentage of staying in existing road 53\% \& percentage of moving to highway $47 \%$

ii. Road of Salatiga-Boyolali : percentage of staying in existing road $60 \%$ \& percentage of moving to highway $40 \%$

i. Analysis of Traffic Volume after the existence of Highway

After the result of trip assignment, the estimated annual volume estimates before the project multiplied by the result of trip assignment.

j. Calculation of Existing Road Saturation Degree and Highway With Project (smp hour) 
Calculation of degree of saturation with the formula DJ $=\mathrm{Q} / \mathrm{C}$, based on the annual traffic volume after the existing of highway above, the result is that the congestion is pulled back several years, that is, in 2038 in Boyolali-Kartasura segment will experience congestion, and in 2029 for Salatiga-Boyolali segment also will experience congestion.

2. Data Processing and Discussion of Economic Aspects

a. Vehicle Operational Cost (BOK)

Based on the unit price analysis multiply by the BOK formula with the PCI method, the following results are obtained:

Table 6. Non Highway BOK Total

\begin{tabular}{cr}
\hline \multicolumn{2}{l}{ Non Highway BOK Total } \\
Gol I & $2,207,199$ \\
\hline Gol II & $3,921,699$ \\
\hline Gol III & $6,911,785$ \\
\hline Gol IV & $8,530,236$ \\
\hline Gol V & $10,318,424$ \\
\hline \multicolumn{2}{l}{ Source: Calculation and Analysis, 2018}
\end{tabular}

Table 7. Highway BOK Total

\begin{tabular}{cc}
\hline \multicolumn{2}{c}{ Highway BOK Total } \\
\hline Gol. I & $2,214,557$ \\
\hline Gol. II & $3,484,274$ \\
\hline Gol. III & $6,859,047$ \\
\hline Gol. IV & $8,605,770$ \\
\hline Gol. V & $10,536,893$ \\
\hline \multicolumn{2}{l}{ Source: Calculation and Analysis, 2018}
\end{tabular}

b. Vehicle operating cost savings

Is a comparison between the value of $\mathrm{BOK}$ without project with $\mathrm{BOK}$ value with project. The calculation of BOK savings is derived from:

BOK Savings = BOK Without Project $-($ BOK With Project + BOK Highway $)$

c. Time value

Obtained from minimum time value and base time value multiplied by per capita factor equal to 0,2 . 
d. The total savings of BOK plus the time-saving are the benefits of this economic analysis, the amount of benefit over the age plan is $\operatorname{Rp} 3,668,941,415,673$.

e. Value of cost during the age plan obtained the results of $\operatorname{Rp} 847,897,263,574$

f. The value of BCR obtained is Benefit / Cost means Rp 3,668,941,415,673 / Rp $847,897,263,574=4.3$. If the value of $\mathrm{BCR}>1$ then the project is economically feasible.

g. Amount of NPV value is Rp 3,409,646,232,099. Value of NPV > 1 then the project is feasible to be done, and it can be concluded that the development of BanyudonoKartasura Highway is economically feasible.

h. IRR value to achieve NPV $=0$ during the age plan is $12.26 \%$, while the Minimum Interest Rate of Return (MARR) obtained from the interest rate of the Bank in the local area is $10.8 \%$. So it can be concluded that the development of Banyudono Kartasura Highway declared feasible because it obtained IRR> MARR.

\section{CONCLUSIONS}

1. Based on the volume without project analysis and calculation results in this thesis, obtained the existing road conditions before the development of Banyudono-Kartasura Highway on Boyolali-Kartasura segment estimated in the year of 2027 there will be an increase of saturation degree to 0.76, Salatiga-Boyolali Road in the year of 2029 there will be an increase of saturation degree to 0.78 . This means that if the saturation degree $>$ 0.75 then it will experience congestion. After the Highway existence the saturation degree becomes lower, for Boyolali-Katosuro segment in 2027 decreased to 0.4 and Salatiga-Boyolali segment decreased to 0.42. This means that with the Highway of Banyudono-Kartasura, can reduce the degree of saturation that exist in the existing road.

2. Based on the trip assignment analysis and calculation by smock method, we get the percentage of vehicle volume that will move to Banyudono-Kartasura Highway. The percentage of vehicles that will move from Boyolali Kartasura road is as much as 47\%, and from Salatiga-Boyolali roads is as much as $40 \%$.

3. Economic feasibility analysis shows Benefit Cost Ratio of 4.3 (BCR > 1), NPV value of Rp 3,409,646,232,099 (NPV > 0). In addition, the IRR value was $12.26 \%>$ MARR $4.48 \%$. So that the construction of Banyudono-Kartosuro Highway is declared feasible from the economic aspect and profitable for road users. 


\section{REFERENCES}

Adhitya Budi Nugraha., 2016., Studi Kelayakan Jalan Tol Bawen-Salatiga Ditinjau dari Segi Lalu Lintas dan Ekonomi., ITS, Surabaya

Agung Yana, Ketut Swijana, dan Santiari Dewi., 2007., Studi Kelayakan Jalan Tol Pengambengan Pengaragoan.,Universitas Udayana., Bali

Departemen Pekerjaan Umum., 2014., Pedoman Kapasitas Jalan Indonesia., Ditjen Bina Marga., Jakarta.

Departemen P.U. 1997. Manual Kapasitas Jalan Indonesia (MKJI), Direktorat Jenderal Bina Marga, Jakarta.

Djoko Susilo dan Christiono Utomo., 2012. Analisa Kelayakan Finansial Pembangunan Jalan Tol Gempol - Pandaan, ITS, Surabaya

Fajrinia, Citto Pacama., 2013., Analisis Kelayakan Pembangunan Jalan Tol Gempol-Pasuruan., ITS., Surabaya

Haming, Murdifin dan Basalamah, Salim., 2010, Studi Kelayakan Investasi Proyek dan Bisnis, Bumi Aksara, Makasar

Hergayasa, Wisnu Arif., 2013.Studi Kelayakan Pembangunan Jalan Tol Krian-Gempol., ITS., Surabaya

Herlianto, Didit dan Pujiastuti, Triani., 2009, Studi Kelayakan Bisnis, Graha Ilmu, Yogyakarta

Hian P, Radityo dan Sagita, Ronny.2005., Perencanaan Jalan Tol Semarang-Kendal., .Semarang UNDIP.

Husnan, Suad dan Muhammad, Suwarsono., 2005, Studi Kelayakan Proyek:, Edisi 4, UPP AMP YKPN, Yogyakarta

Istiyawan, Arief.2010., Studi Kelayakan Pembangunan Jalan Lingkar Timur Mojosari Kabupaten Mojokerto., :ITS,. Surabaya

Kamidjo Rahardjo .2007., Studi Kelayakan Investasi Jalan Tol Segmen Lawang-Purwosari, ITN ,Malang

Kodoatie, R J. 1995. Analisis Ekonomi Teknik, Penerbit Andi Offsef, Yogyakarta.

Lalu Ardian Bagus Nugroho,. 2016., Analisa Kelayakan Ekonomi Bendungan Randu Gunting Kabupaten Blora,. Unissula., Semarang

Peraturan Pemerintah Replubik Indonesia, Nomor 15 Tahun 2005. Tentang Jalan Tol

Sekretariat Negara, 2004, Undang-Undang Republik Indonesia Nomor 38 tahun 2004 Tentang Jalan, Tambahan Lembaran Negara Republik Indonesia Nomor 132, Jakarta.

Tamin, Ofyar Z. 2000. Perencanaan dan Pemodelan Transportasi. Edisi Ke-2. Bandung: ITB Bandung.

Undang-Undang Replubik Indonesia, Nomor 38 Tahun 2004, Tentang Jalan. 